\title{
Global cochineal production: scale, welfare concerns, and potential interventions
}

Global cochineal production: scale, welfare concerns, and potential interventions

Summary of conclusions

$\underline{\text { Terms }}$

Introduction

History of cochineal use

Cochineal production figures

Cochineal production details

$\underline{\text { Welfare concerns }}$

Potential interventions

More certain: reducing the number of farmed cochineal

Less certain: advocating for specific dyes

Less certain: advocating for greenhouse production

Areas for further research

Improving scale estimates

Sentience research

Research on kermes and Polish cochineals

Research into scale insects used for biological control and shellac production

Research into labeling and alternative dyes

Acknowledgements

$\underline{\text { Sources }}$

\section{Summary of conclusions}

- Between 22B and 89B adult female cochineals are killed per year directly to produce carmine dye, of which between $17 \mathrm{~B}$ and $71 \mathrm{~B}$ are wild, and between $4 \mathrm{~B}$ and $18 \mathrm{~B}$ are farmed

- The farming of cochineals directly causes $4.6 \mathrm{~T}$ to $21 \mathrm{~T}$ additional deaths, primarily of male and female cochineal nymphs, and adult male cochineals 
- The deaths of nymphs are possibly the most painful caused by cochineal production

- The vast majority of cochineal is produced in Peru, followed by Mexico and the Canary Islands

- Reducing cochineal farming, which accounts for $15 \%$ to $25 \%$ of the market, would significantly reduce cochineal suffering

- Reducing wild cochineal harvesting is unlikely to have any significant effect on cochineal suffering

- Accordingly, insect advocates interested in reducing cochineal suffering ought to focus on eliminating cochineal farming specifically, and not necessarily all cochineal harvesting

\section{Terms}

Farmed cochineals

- Female cochineals intentionally added to cacti to produce dye Wild cochineals

- Cochineals that live independently of farming. Adult females are killed to produce dye, but because they are generally killed at the end of their lives, farming may not significantly impact their population

Harvested cochineals

- Adult female cochineals killed for dye - primarily wild but some farmed. Harmed non-harvested cochineals

- The male and female offspring of farmed cochineals who in the case of females do not survive to adulthood or are not harvested. This report only addresses insects who exist due to the industry, and not the offspring of wild cochineals harvested for dye production

\section{Introduction}

Cochineal is the name of both a type of insect and an extract produced from that insect. The extract produced from the insect is used to produce carmine, a deep red dye used primarily in food and cosmetics. The insect that is typically used to produce cochineal is Dactylopius coccus, though a variety of other insects in the genus Dactylopius are used to produce carmine dyes, and they can be difficult to differentiate. Additionally, there are other types of carmine produced from scale insects not in the genus Dactylopius, such as kermes or Polish cochineals. These carmine dyes are similar chemically, despite the insects being taxonomically distinct. 
Carmine dye is produced from carminic acid, which the female insects produce to deter predators. Female insects are mostly immobile. Young nymphs move to a spot on a cactus typically of the Opuntia genus, and secrete a waxy white substance over their bodies, which protects them from the sun and water loss. They feed off the cactus for the entirety of their lives. The female cochineals remain immobile for most of their lives, unless they are disturbed. They live to around 70 to 90 days in the wild (Klein 2002).

Cochineals are harvested, and dried out, and ground up, producing a powdered dye, which is dark red. The extracted dye can be used to produce carmine lake or carminic acid, both of which are common food or cosmetic additives in red products, such as grenadine or lipstick. Cochineal products are listed as a food or cosmetic ingredient as E120, natural red 4, carmine, or crimson lake.

I estimate that between $22 \mathrm{~B}$ and $89 \mathrm{~B}$ cochineals are killed per year directly to produce dye, of which between $17 \mathrm{~B}$ and $71 \mathrm{~B}$ are wild, and between $4 \mathrm{~B}$ and $18 \mathrm{~B}$ are farmed (this difference is discussed later). Additionally, the farming of cochineal directly causes 4.6T to $21 \mathrm{~T}$ deaths, including of male and female cochineal nymphs, and adult male cochineals. I think it is plausible that the majority of these deaths would not occur if cochineal farming ceased, and that the majority of the suffering caused by cochineal production is due to farming.

\section{History of cochineal use}

Cochineal has been used as a dye in South America for thousands of years. Imported cochineal began being sold in Europe in around 1540, brought by Spain from South America. Cochineal provided Europe with a source for inexpensive red dye, which at the time was in high demand.

By the 18th century, the cochineal market had regulations on imports, ensuring purity and quality of production. Cochineal production has primarily remained in South America - Peru has long been the world's largest producer, continuously producing between $85 \%$ and $95 \%$ of global cochineal by weight (Green, 1995). The Spanish brought cochineals to the Canary Islands, which are now the second largest producer. However, in recent decades, Mexico has significantly increased cochineal production.

Additionally, an effort has been made to produce cochineal in Ethiopia on nopales cacti. This attempt by a Chilean company, Foodsafe, to dominate the cochineal market in the early 2000s failed, though for a short time thousands of tonnes of cochineal were produced. Enough cochineals were harvested to produce up to 12,000 tonnes of dye, 
though much of it was never exported. Now, the cacti and insects have spread significantly in the country (Tesfay 2015).

As many as 3,000 tonnes of cochineal were produced in 1875 (Green 1995). However, after the invention of synthetic dyes in the 20th century, production has dramatically declined. By the 1990s, production was below 1000 tonnes. Because cochineal has a relatively long shelf life, it seems likely that production varies dramatically from year to year. Now, the market is much smaller - possibly between 200 and 700 tonnes produced per year in total.

\section{Cochineal production figures}

My figures and model for estimating population can be found here. Note that there is not particularly good information on the scale of cochineal production, and there is a lot of yearly variation in total production. Cochineal extract has a long shelf life, so overproduction one year might reduce the amount harvested in the following year. It is unclear how this variation impacts total cochineal farming, and is a primary contributor to uncertainty in the estimate $\left(r^{2}=0.70\right)$. Additionally, there is some uncertainty due to a lack of information on how many cochineals need to be killed to produce a unit of carmine, and the terminology in a lot of the published research is vague, unsourced, or provides extremely large ranges $\left(r^{2}=0.23\right)$.

I estimate that the number of adult female cochineal insects killed for cochineal dye to be between 22 billion and 89 billion a year. However, the majority of cochineals killed directly are not "farmed" - they are harvested from wild cacti. The number of adult female cochineals added by the industry is 4 billion to 18 billion.

Additional cochineal insects are killed due to cochineal production - only the adult females are harvested for dye, but nymphs and males are also born. My estimate is that an additional 3 trillion to 14 trillion male nymphs and adults, and 1.5 to 7.3 trillion female nymphs who otherwise would not have been born die due to the farming of cochineal. This suggests that the total deaths caused by the cochineal industry per year is likely between 4.6 trillion to 21 trillion. Some market research suggests that the cochineal market is growing steadily, so this number may increase in the coming years. However, these reports don't differentiate between synthetic, natural, and insect-derived carmine, so the exact trend is unclear (Grand View Research 2018). 


\section{Cochineal type}

Farmed adult females

Wild adult females

Total adult females killed for dye

Male nymphs and adults added by farming

Females nymphs added by farming

Total deaths added through farming

Total deaths caused by industry
Total deaths

$4 \mathrm{~B}$ to $18 \mathrm{~B}$

$17 \mathrm{~B}$ to $71 \mathrm{~B}$

$22 B$ to $89 B$

$3 \mathrm{~T}$ to $14 \mathrm{~T}$

1.5T to $7.3 \mathrm{~T}$

$4.6 \mathrm{~T}$ to $21 \mathrm{~T}$

$4.6 \mathrm{~T}$ to $22 \mathrm{~T}$

Fig. 1. Deaths added or caused by the cochineal and carmine industries. Note that the direct deaths - females killed for dye, make up only a tiny fraction of the total insects who die due to the cochineal industry.

\section{Cochineal production details}

While most cochineals are harvested from wild colonies on Opuntia cacti (Emmett 2002), cochineal are also farmed. There are two primary farming methods, traditional and controlled. In traditional farming, cochineal infested cactus pads are planted, or cochineals are added by hand to wild cacti. In controlled farming, baskets called Zapotec nests (figure 2) are added to host cacti. The baskets contain females, who settle on the cacti and reproduce. Typical female cochineal lifespan is around 70 to 90 days, and they are harvested close to their natural deaths, so that they grow as large as possible.

Note that there is a small amount of greenhouse and plastic microtunnel cochineal production. Most of this production occurs in Mexico (Campos \& Celina 2003). 


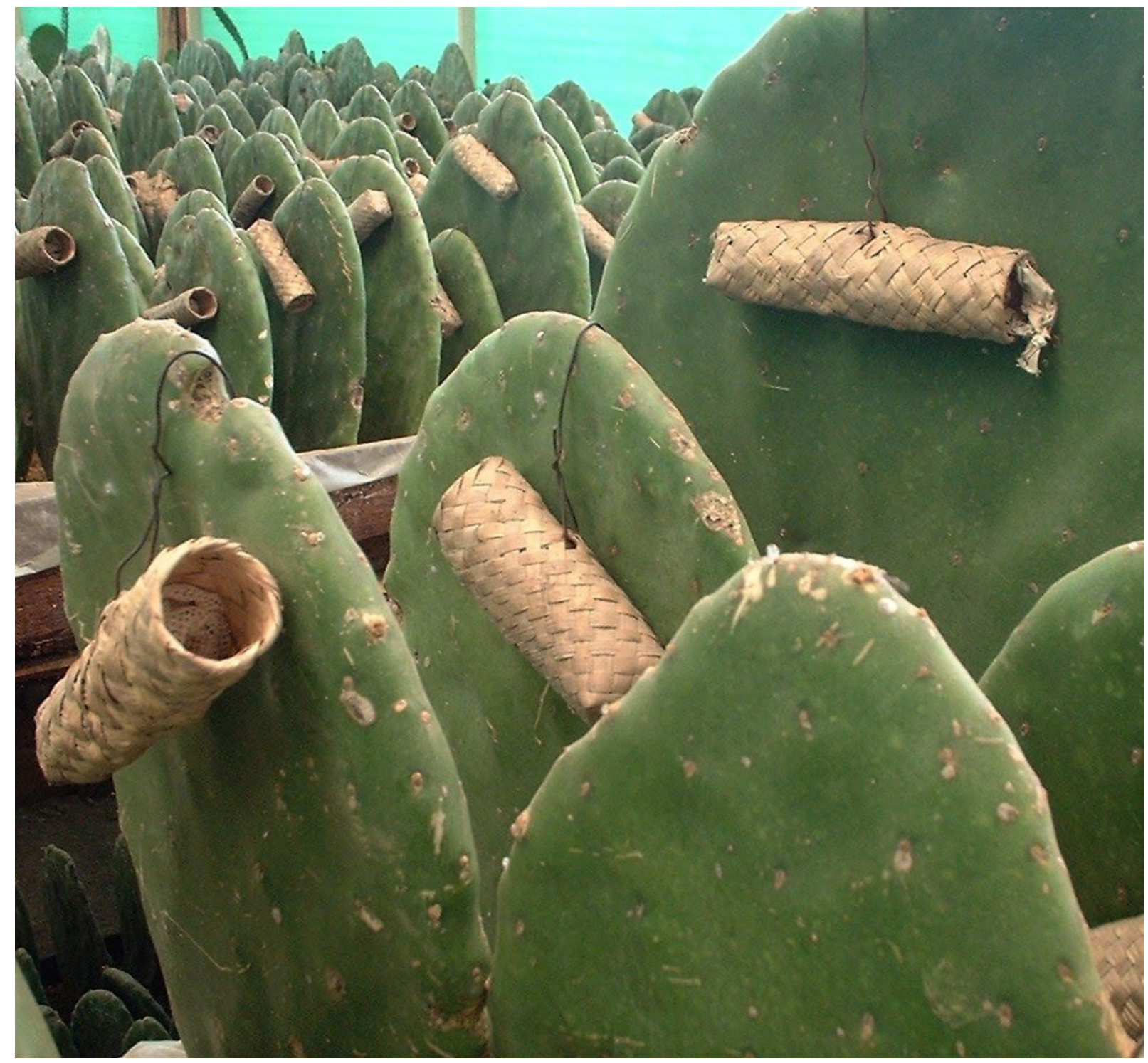

Fig. 2. Zapotec nests on Opuntia cacti. 


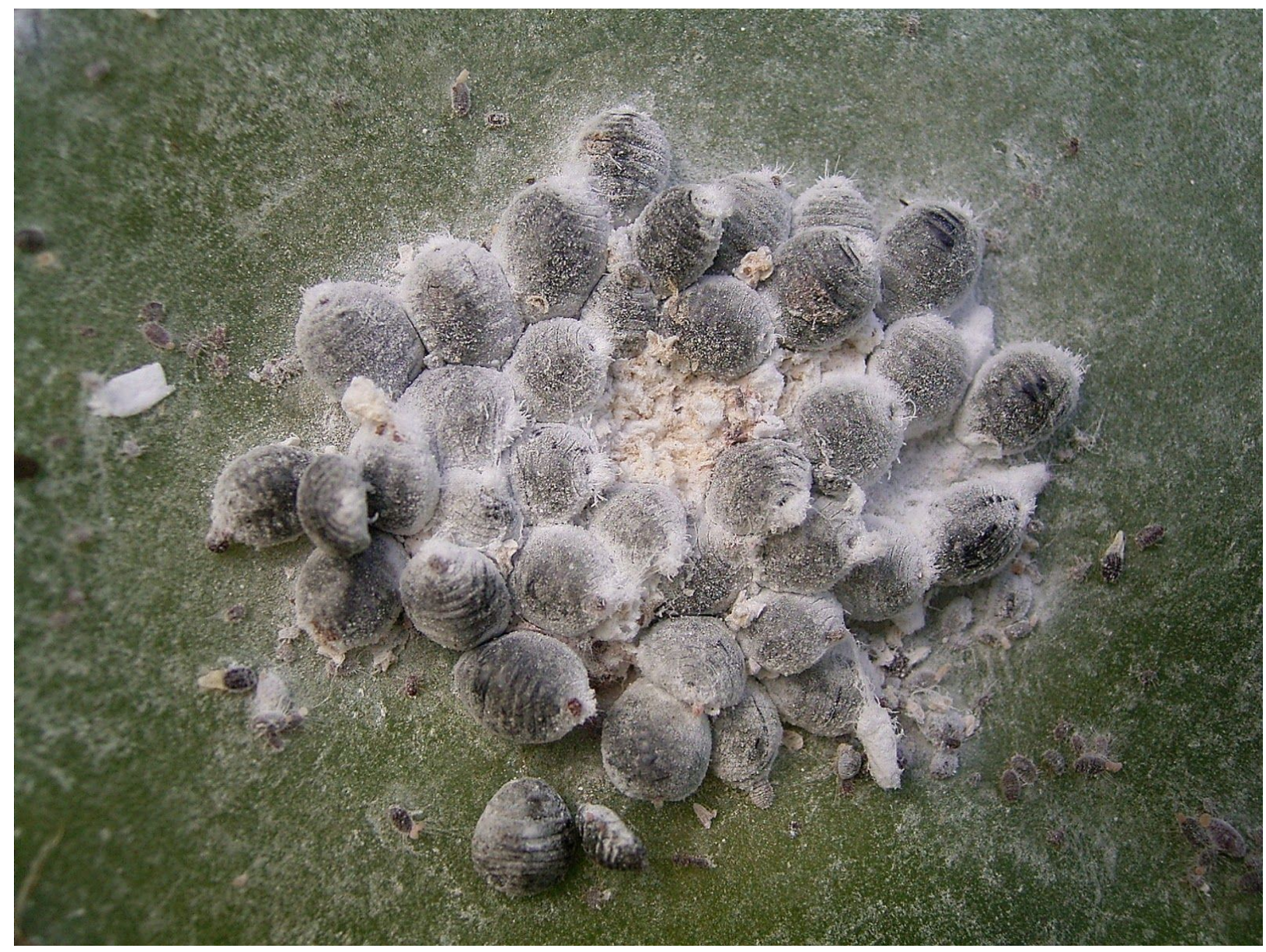

Fig. 3. Cochineal adult females under scale coating on a cactus.

Adult female cochineal insects are typically harvested by hand. Some are used immediately to reinfest other cacti, but most are killed to produce dye. Four methods are used: immersion in hot water, exposure to sunlight, steam, or dry heat (e.g. an oven). The method of killing affects the color of the dye, so is determined by demand for specific colors. Insects are then dried to around 30\% of their body weight. Then, they are ground and the carminic acid is extracted to produce the dye (Nejad and Nejad 2013). It seems possible that the majority are killed by immersion in hot water (Kendrick 2012), although the exact totals are unclear.

While adult females are the only cochineals harvested for dye, other cochineals die due to cochineal production. A female insect on average produces 1100 to 1250 successful offspring over the course of her life (Moran and Cabby 1979). The nymphs are referred to as "crawlers" as they are mobile, unlike the adult females (who only move under duress). The female nymphs crawl to the tops of cacti, and use wind to disperse to other local cacti, traveling up to several meters. The vast majority do not successfully land on 
a new cactus, and are forced to climb up from the ground and try again over and over again. Most female crawlers will die of starvation during this period (Moran and Cabby 1979, Klein 2002).

Female crawlers that successfully land will find a suitable spot on the cactus, insert their mouthparts, and feed off the cactus for the rest of their lives. They go through physical changes, moulting and growing long waxy filaments or releasing a waxy powder, depending on the species (figure 3). Their legs become immobile. A female crawler who removes its mouthparts after attaching will never be able to feed again and will die of starvation. This moulting and physical change takes around 3 weeks. Then for the remainder of their life, usually around 50 days, female cochineals will lay eggs (Klein 2002). Depending on environmental conditions, especially population density, egg mortality rates are between $2.7 \%$ and $37.4 \%$ (Moran and Cabby 1979). Significantly fewer females die if population density is sufficiently low on their birth cactus, as they can feed off it, and do not have to attempt the dangerous wind dispersal technique (Klein 2002). However, given the extremely large cohort sizes of cochineals, this is unlikely a successful strategy over multiple generations.

Male crawlers typically only live for a few days (Klein 2002). They do not disperse from their mother immediately, and spend the first few days of their lives feeding under her. They then form a cocoon of waxy filaments, and emerge winged. They mate with up to one female prior to starving to death or dying by predation - they do not feed as adults. While one author claims that the vast majority of males die of starvation (Moran and Cabby 1979), there isn't clear data informing this claim.

Adult female cochineals face a variety of threats besides starvation. They are especially sensitive to sunlight, secreting waxy coatings as a protection method (Moran and Cabby 1979). They also face extensive predation. Insects like ladybugs, moths, lacewings, wasps, and even reptiles and birds feed on cochineals (figure 4). However, the vast majority of cochineals seem to die by starvation. 


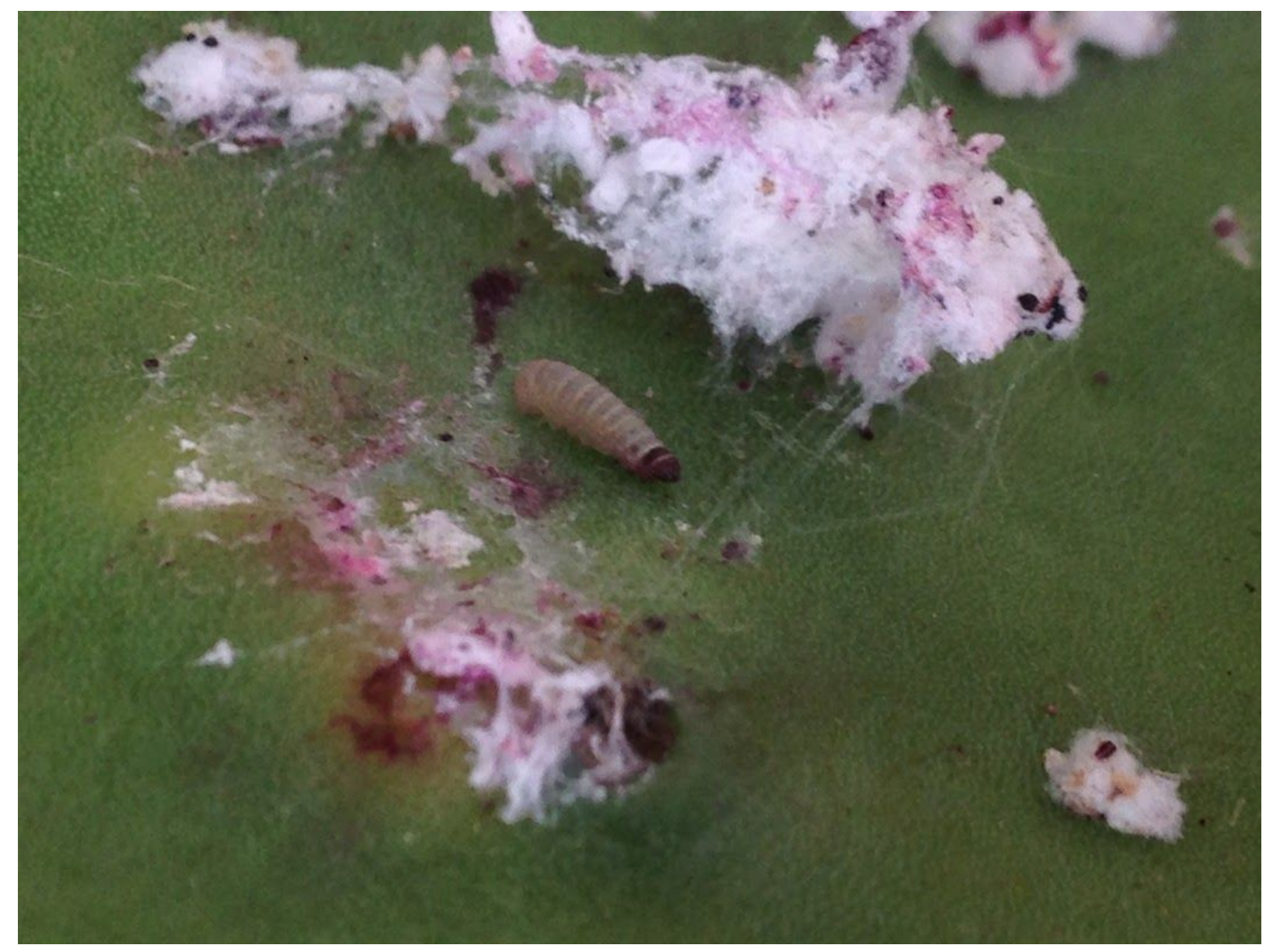

Fig. 4. A Laetilia coccidivora caterpillar feeding on cochineal scales. The species of moth feeds exclusively on scale-bugs. They use the carminic acid as a defense mechanism against their own predators. This caterpillar did not survive to adulthood - the parasitic wasp Brachymeria conica laid eggs in it, later leading to its death.

\section{Welfare concerns}

Insect welfare advocates should primarily be concerned about the deaths of cochineal crawlers, and not the deaths of the adult female cochineals used for dye themselves not only do crawlers make up the vast majority of impacted insects, they die painfully (most likely by starvation) and at a young age. The deaths of the females used for dye seem to be quicker than the deaths of the crawlers, which would be less painful, all other things being equal (or equally uncertain).

It seems possible that most female crawlers die of starvation, as do most male adults. Typically, it takes around 3 to 5 days for death by starvation for both the crawlers and the adults (Klein 2002). All male adults die within a fews days of metamorphosing. If they aren't killed, they starve to death. It is unclear how painful this death is, as they do 
not have the ability to eat, and pain related to starvation might not be present. But, given that we'd expect starvation to be painful for crawlers, then it is possible this experience holds over into the adult stage.

Regardless, the available information, which is extremely limited, suggests that the worst lives are had by female crawlers, followed by male nymphs and adults, followed by the adult females.

\section{Potential interventions}

\section{More certain: reducing the number of farmed cochineal}

Depending on the approach, reducing the number of farmed cochineals might significantly reduce the suffering of female nymphs, male nymphs, and adult males who are born to farmed female cochineals. I do not believe that a reduction in cochineal production outside farming (i.e., stopping the harvesting of wild cochineal) would significantly decrease cochineal suffering, as the females are harvested toward the end of their lives, and it is possible that deaths due to production are less painful than their natural deaths.

The primary impact on a reduction in total cochineal farming would be preventing trillions of cochineals who likely die painfully shortly after birth from ever existing.

Depending on how such a reduction was approached, it might not actually decrease total cochineal production. For example, wild cochineals are abundant in Ethiopia, but the country does not produce significant amounts of cochineal. If farming was banned in countries like Peru and Mexico, it is possible that production would just shift to wild caught cochineals in Ethiopia. Note that this would likely still lead to an overall reduction in cochineal suffering, as significantly fewer cochineals would die. The Ethiopian cochineals are already dying in the wild.

Besides outright bans, and depending on the economics of production (on which there is almost no publicly available information), promoting synthetic or non-insect natural dyes might be an alternate way to decrease cochineal production, and as a result, decrease cochineal farming.

Synthetic dyes are already cheaper than insect cochineal extract. This is likely the cause of cochineal production decreasing by thousands of tonnes over the last 150 years. However, significant production of cochineal still occurs, and the "naturalness" of 
cochineal derived dyes makes them popular for high-end consumer goods, such as fancy grenadine. The failure of synthetic dyes to completely replace insect cochineal may be attributable to aesthetic preferences by consumers of high-end brands. Or, it may be attributable to lack of information. While insect-derived cochineal must be labeled as such in some countries, consumers are still not widely aware of the source of these red dyes. In 2012, after it was publicly reported that they used insect-derived dyes in drinks, Starbucks bowed to consumer pressure and switched to tomato-derived dyes.

However, there are potential alternatives to cochineal that might serve a similar purpose while seeming just as natural - fermented cochineal is a new kind of carmine dye made entirely from plants. It seems possible that campaigning to replace insect cochineal with fermented cochineal would be successful, as it is a naturally produced alternative. Unfortunately, fermented cochineal may not be on the market for several years (Scott-Thomas 2015). Other natural alternatives to carmine, such as dyes made from sweet potatoes, are already on the market. They are not chemically identical to insect-cochineal, but are similar in color.

\section{Less certain: advocating for specific dyes}

Ending the use of wild cochineals to produce dye would likely have negligible impacts on total welfare. The cochineals who are killed are already toward the end of the natural lifespans, and many of the methods of killing cochineals might take significantly less time than the way they'd die otherwise. While duration of painful experience is not the same as total pain of death, it seems like a useful proxy, and the relatively quick death of being crushed or boiled seems possibly less painful than multiple days of starvation.

This suggests that one way to reduce cochineal suffering during production might be advocating for greater use of specific dyes. It seems that variations in dye color are brought about by the type of death. Advocating for the dyes produced using the least painful methods would impact both farmed and wild cochineals. Note though, that vastly more suffering might be prevented by simply reducing or ending cochineal farming.

I note that this intervention is less certain because there is basically no research I can find on the relationship between duration of death and method of killing, and the intervention as a whole is rather speculative. Additionally, this intervention would only impact the harvested cochineals themselves, which make up a small minority of total cochineals who die due to farming and production. 


\section{Less certain: advocating for greenhouse production}

In Mexico, some producers use greenhouses or plastic microtunnels to cover the cacti during production of cochineal. Using greenhouses significantly increases the productivity per cacti. It also reduces predation significantly (Campos \& Celina 2003), though not entirely (Cristobal \& Celina 2005). This increased productivity may be due to decreased female juvenile mortality. If female juvenile mortality is decreased, and more of those females are later harvested to produce dye, the overall number of deaths caused by cochineal production would in turn be reduced by about the same degree.

Cochineal advocates might work to establish the use of greenhouses in cochineal farming, reducing the deaths of nymphs by protecting them from predation and the elements.

I am less confident in this intervention as there is minimal research on the actual effectiveness of using greenhouses on the survival rates and fecundity of cochineals.

\section{Areas for further research}

\section{Improving scale estimates}

The information on cochineal production is all dated and inconsistent. There seem to be few public estimates of total production made since the 1990s, and information on how many cochineals are killed to produce the dye is also extremely sparse or unclear. Research into both the scale of production and the number of animals impacted by production would help clarify the scale of cochineal suffering.

\section{Sentience research}

This article assumed cochineals are sentient. There is very little evidence supporting this assumption. The Rethink Priorities survey of insect sentience research did not evaluate any insects in the same taxonomic order as cochineals, Hemiptera. Further research or literature reviews on cochineal behavior and anatomy might help clarify this uncertainty.

\section{Research on kermes and Polish cochineals}

Cochineals are not the only scale insects (Superfamily Coccoidea) used to produce dye. Kermes and Polish (or Armenian) cochineals are other insects within Coccoidea that are similarly used to produce carminic acid as a dye. The scale of contemporary production of these species appears to be extremely small, but further research might clarify if there are additional concerns. 


\section{Research into scale insects used for biological control and shellac production} Tangentially, scale insects related to cochineals are also used as a biological control agent for Opuntia cacti, and to produce shellac (cochineals and lac bugs (Kerria lacca) are taxonomic cousins). I plan on researching and publishing reviews of both these industries (and other biological control insects) in the near future.

\section{Research into labeling and alternative dyes}

Finally, I spent very little time evaluating why cheaper synthetic and natural alternatives to insect carmine have failed to completely eliminate cochineal harvesting. More time could be spent studying these industries, and evaluating their potential for reducing cochineal production in the near future.

Additionally, some countries have policies requiring the labeling of cochineal as being insect-derived. One area of uncertainty is how these labeling laws impacted sales. Research into the impact of labeling could help inform future interventions.

\section{Acknowledgements}

Thanks to Jason Schukraft and Michelle Graham for providing feedback and comments on this research.

\section{Sources}

Campana, M, Garcia NMR, \& Tuross, N (2015) America's red gold: multiple lineages of cultivated cochineal in Mexico. Ecology and Evolution, 5(3): 607-617.

doi: 10.1002/ece3.1398

Campos, M \& Celina L (2003) Greenhouse production of cochineal insect Dactylopius coccus (Homoptera : Dactylopiidae). Agrociencia 37(2): 149-155.

Cochineal Color Peru (2020) <http://cochineal.org/>. Accessed 2020-02-11.

Cochineal Extract (2000) Joint FAO/WHO Expert Committee on Food Additives (JECFA).

Cristobal A \& Celina L (2005) Cochineal (Dactylopius coccus Costa) production in prickly pear plants in the open and in microtunnel greenhouses. Agrociencia 39(2): 161-171. 
Donkin, RA (1977) Spanish red: an ethnographical study of cochineal and the Opuntia cactus. Transaction of the American Philosophical Society 67(5): 1-35.

Emmett, S (2002) Seeing red. New Agriculturalist 02:3. $<$ http://www.new-ag.info/02-3/develop/dev02.html>.

Flores-Flores, V, Tekelenbuerg, A (1995) Dacti (Dactylopius coccus Costa) dye production. In: Agroecology, cultivation and uses of cactus pear. FAO Plant Production and Protection 132:167-185.

Foote, W (1996) The land that cried blood: rebuilding the kingdom of cochineal in Oaxaca. ICWA Letters. WF-12: The Americas.

Grand View Research (2018) Carmine Market Size, Share \& Trends Analysis Report By Application (Beverages, Bakery \& Confectionery, Dairy \& Frozen Products, Meat, Oil \& Fat), By Region, And Segment Forecasts, 2018 - 2025.

$<$ https://www.grandviewresearch.com/industry-analysis/carmine-market $>$. Accessed 2020-02-11.

Green, CL (1995) Natural colorants and dyestuffs: a review of production, markets and development potential. Food and Agriculture Organization of the United Nations.

Gunn, BH (1979) Dispersal of the cochineal insect Dactylopius austrinus De Lotto (Homoptera: Dactylopiidae). - Ph.D. thesis, Rhodes University, South Africa.

Kendrick, A (2012) Carminic acid/carmine from Natural Food Additives, Ingredients and Flavourings, chapter 2.2.9. Woodhead Publishing. ISBN: 978-1-84569-811-9.

Klein, H (2002) Biological control of invasive cactus species: cochineal insects (Dactylopius spp.). ARC-Plant Protection Research Institute Leaflet Series: Weeds Biocontrol, No 2.2.

Moran, V \& Cabby, B (1979) On the life-history and fecundity of the cochineal insect, Dactylopius austrinus De Lotto (Homoptera: Dactylopiidae), a biological control agent for the cactus Opuntia awantiaca. Bulletin of Entomological Research, 69(4): 629-636. doi: $10.1017 / S 0007485300020174$ 
Nejad, HE \& Nejad AE (2013) Cochineal (Dactylopius coccus) as one of the most important insects in industrial dyeing. International journal of Advanced Biological and Biomedical Research, 1(11): 1302-1308.

Rodriguez, LC \& Pascual U (2004) Land clearance and social capital in mountain agro-ecosystems: the case of Opuntia scrubland in Ayacucho, Peru. Ecological Economics 49(2): 243-252. doi: 10.1016/j.ecolecon.2004.03.023

Scott-Thomas, C (2015) Natural without the bugs? Chr Hansen develops fermented cochineal. Food Navigator. Retrieved 2020-02-02.

$<$ https://www.foodnavigator.com/Article/2015/06/23/Natural-red-without-the-bugs-Chr -Hansen-develops-fermentation-derived-carmine>.

Tesfay B (2015) Carmine Cochineal: fortune wasted in Northern Ethiopia. Tigray Agricultural Research Institute, Mekelle Agricultural Research Center.

Tovar, A, Pando-Moreno, M, \& Garza, C (2005) Evaluation of three varieties of Opuntia ficus-indica (L.) Miller as hosts of the Cochineal insect Dactylopius coccus costa (Homoptera: Dactylopiidae) in a semiarid area of northeastern Mexico. Economic Botany 59, 3-7. doi: 10.1663/0013-0001(2005)059[0003:EOTVOO]2.0.CO;2

Zaya, P (1998) Carmine Dye Extraction Process and the Cochineal Insect. International Development Research Centre, Simon Fraser University. 